\title{
ISOMORPHISM: AN EXPLANATION FOR THE POPULARITY OF PUBLIC-PRIVATE PARTNERSHIPS?
}

\author{
Dr Ciaran Connolly \\ Queen's University Management School \\ Dr Eoin Reeves \\ Department of Economics, University of Limerick \\ and \\ Anthony Wall \\ Department of Accounting, University of Ulster
}

\begin{abstract}
While Public-Private Partnerships (PPPs) are a popular public policy tool, there is evidence to suggest that they often fail to deliver value for money, a key objective. Focusing on the use of PPPs in education in Ireland, this paper draws on perspectives from institutional and isomorphic theories to illuminate the use of PPPs as a modernisation tool of government. It finds that, while the adoption of PPPs has been characterised by difficulties, policy makers persist with their use. This is attributed to coercive isomorphic pressures in the case of Northern Ireland and mimetic isomorphic pressures in the Republic of Ireland.
\end{abstract}

\section{INTRODUCTION}

Over the last 25 years governments around the world have implemented a host of market-based reforms in an attempt to improve the efficiency and effectiveness of public service delivery. These reforms have often been promoted under the banner of 'modernisation' (Giddens, 1998) and have been adopted in response to rising public expectations (Arnaboldi and Lapsley, 2003). However, while portraying a commitment to public services, they are also a declaration that core public services are not performing as well as they should (Benington, 2000). Collectively, these reforms have been referred to as New Public Management (NPM) and they seek to improve planning, performance and accountability in the public sector. NPM reforms, which include the particular implementation tool 
Connolly, Reeves \& Wall

addressed in this paper - Public-Private Partnerships (PPPs) - have had major impacts on many western governments (Guthrie, Olson and Humphrey, 1999; Hood, 1991; Pollitt and Bouckaert, 2000). This paper explores why governments continue to employ PPPs as a key part of their investment strategy for modernising public sector infrastructure and service delivery in the face of doubts about their rationale and emerging evidence that question whether PPPs achieve their ascribed goals. The paper begins by examining the validity of the arguments commonly offered in favour of PPPs. It reviews the track record of PPPs and asks why the PPP procurement model continues to be attractive to policy makers. Drawing on institutional and isomorphic theories, the latter of which refers to a constraining process that forces one part of a population to resemble other parts that face the same set of environmental conditions, the paper attempts to address this question with reference to the use of PPPs in education in Ireland. ${ }^{1}$ The paper concludes by assessing the impact of PPPs on the Irish education sector and considering what lessons can be learnt.

\section{THE POLICY CONTEXT}

\section{PPPs: A Global Phenomenon}

Since the mid-1990s PPPs have become evermore popular as governments increasingly engage the private sector in the provision of public services. The term PPP can be applied to any collaboration between public bodies, such as local authorities or central government, and private companies, and includes the transfer of council homes to housing associations using private loans and the contracting out of services such as refuse collection, portering and hospital cleaning (Her Majesty's Treasury (HMT), 2000; Osbourne, 2000). The Private Finance Initiative (PFI), arguably the most well-known form of PPP, refers to a strictly defined legal contract for involving private companies in the construction and provision of major public sector infrastructure assets and associated services.

The PFI was launched by the United Kingdom (UK) Conservative government in 1992 and subsequently embraced by New Labour. ${ }^{2}$ Under PPP, a private sector company is contracted to design, build, finance and operate (DBFO) a capital project such as a school, prison or hospital. ${ }^{3}$ For larger projects, a consortium of private sector companies (usually comprising a building firm, a finance company and a service provider) or Special Purpose Vehicle (SPV) is often formed. While the UK is generally regarded as the region that has gone furthest in terms of adopting PPPs, overall activity has expanded in recent years. PricewaterhouseCoopers (2005) estimated that in the years 2004 and 2005 approximately 206 PPP deals worth approximately $€ 42$ billion were closed worldwide. Moreover, between 1994 and 2005 it is estimated that PPP deals with a value of approximately $€ 100$ billion closed across Europe, with two-thirds of these being in the UK.

Research on UK PPPs has tended to focus on health (for example, British Medical Association, 1997; Gaffney and Pollock, 1999; Gaffney, Pollock, Price and 
Shaoul, 1999; Mayston, 1999; Froud and Shaoul, 2001; Broadbent, Gill and Laughlin, 2003) and education (for example, Ball, Heafey and King, 2000, 2003a, 2003b; McCabe, McKendrick and Keenan, 2001; McFadyean and Rowland, 2002), although roads (Edwards, Shaoul, Stafford and Arblaster, 2004; Shaoul, Stafford and Stapleton, 2006), defence (Kirk and Wall, 2002) and prisons, particularly the controversial refinancing of Fazakerley prison (National Audit Office (NAO), 1997, 2002), have also been examined.

\section{PPPs: Inadequately Rationalised and Empirically Unproven}

It could be argued that PPPs are part of the broader agenda of privatisation undertaken by successive UK governments. This has resulted in the privatisation of key institutions such as British Gas and the water utility industry, while, at the same time, in the case of PPPs it has provided increasing levels of collaboration with the private sector. PPPs have been promoted as a means of encouraging private sector involvement in public sector projects and acquiring private sector management expertise for the public sector (McKendrick and McCabe, 1997). The model is seen as a means of bringing the benefits of privatisation, such as improved efficiency and better value for money (VFM) for the taxpayer, to that part of the public sector, which, either for political or technical reasons, could not be straightforwardly privatised (Heald and Geaughan, 1997).

The assertion that PPPs can serve as a vehicle for much needed upgrading of infrastructure, whilst keeping within public expenditure limits, is commonly offered as a justification for its adoption. Proponents argue that they allow government to finance more infrastructure projects than would have been possible conventionally as the private sector makes the up-front investment, with the state making periodic payments in the future (NAO, 1999; Grimsey and Lewis, 2002). Indeed, supporters claim that many hospitals and schools would not otherwise have been built as public money was simply not available. The validity of this assertion however depends on whether PPP investment is in addition to, rather than a substitute for, traditional public spending. There is evidence from both the UK (Hall, 1998; Commission on Public Private Partnerships, 2001) and Ireland (Reeves, 2003) to suggest that the approval of some capital investment has been contingent on adopting PPPs. In other words, PPP is the only game in town.

A major attraction for policy makers is the potential for securing infrastructure investment without recourse to public sector borrowing. Although PPP enthusiasts have never claimed that it would directly increase the money available for capital projects, two major advantages were envisaged. First, budget savings would be achieved by managing spending more effectively, which in turn would lead to more projects being undertaken. However, a significant obstacle to this is the relatively higher cost of private sector borrowing. Second, despite the required private sector return, projects have a better chance of proceeding as there is less of an immediate impact on public spending since payments are spread over the life of the contract. However, this latter argument is less relevant following the introduction of Resource Accounting and Budgeting (RAB) in the UK, which 
requires that money spent is recorded in the year incurred, not in the year spent (unless the two are the same) (Hall, 1998).

A key argument advanced by proponents of PPPs is that they involve transferring risks to those parties best equipped to cope with them, thereby shifting the risk of delivery to the contractor. PPPs therefore motivate the SPV to deliver within budget and on time as a result of the incentives offered through the payment mechanism and also due to unitary payments not beginning until the asset is operational (NAO, 2003). Risk transfer is also seen to have benefits following construction. If PPP contractors fail to perform operations or maintenance at an agreed standard they do not get paid and the purchaser can spend the money elsewhere to make improvements.

How this operates in practice depends on the precise contract terms and the extent to which they are enforced. Moreover, it has been questioned whether PPP really does transfer risk, deliver VFM and provide cost savings (for example, Ball et al., 2000; Wakefield and Valentine, 2001; Heald, 2003). Gaffney et al. (1999) query why the taxpayer should pay to devolve risk that can be addressed through internal action by the National Health Service Executive, and Froud (2003), with reference to risk and uncertainty, suggests that while the latter can only be dealt with by government it is largely ignored in PPP contracts. There is a significant body of evidence that demonstrates unwillingness by the private sector to bear risk. In the education sector, for example, Ball et al. (2000, 2001) analysed a high school project where intensive negotiations resulted in significant reductions in private sector risk by reducing instances where penalties could apply. It is also the case that once PPP contracts are operational they are rarely terminated, often due to potentially high litigation costs (Hencke, 2003). Where contracts are terminated the burden ultimately falls on the taxpayer and service users. For example, one of the two companies contracted to rebuild the London Underground network went into administration in July 2007 (Glaister and Travers, 2007), which could cost the taxpayer as much as $£ 2$ billion.

In light of this, it is not surprising that the evidence demonstrating that PPPs deliver VFM is scarce. Given that PPPs are long-term contracts, VFM estimates are confined to the ex ante contracting stage, which involves estimating the cost of using conventional public funds (the public sector comparator (PSC) in the UK) and comparing this with a hypothetical PPP project. In reality this has meant that an up-front, traditional procurement payment is compared with a discounted PPP project. However, it is arguably easy to demonstrate that the PPP option provides better VFM by simply manipulating the discount rate by a fraction of one per cent to 'prove' public provision would be dearer and ensure the PPP option (for which funding is available) gets accepted (McKendrick and McCabe, 1999; Pollock, Shaoul and Vickers, 2002; Froud, 2003). One of the reasons for this may be that the public sector purchasers believe that no other route is available to them apart from PPP and thus indicate to the advisors that the PPP bid should always be lower. Other criticisms of the PSC are that risk premiums are factored in to weight the decision in favour of the private sector; in some jurisdictions private contractors can reclaim Value Added Tax (VAT), while the public sector has no tax relief on its projects; and certain public sector projects might have been costed on the basis 
of traditional technology and construction methods, possibly allowing private sector bids to be lower due to the use of innovative techniques (McKendrick and McCabe, 1999). In addition, VFM tests take no account of differences in quality - a key issue in public service delivery.

Arthur Andersen (2000), one of the earliest VFM studies of UK PPPs, reported average cost savings of 17 per cent, although a number of writers (Hodge, 2004; Ball et al., 2001) have noted that the bulk of these cost savings were attributable to risk transfer. The Commission on Public Private Partnerships (2001) concluded that PPPs showed considerable cost savings of approximately 15 per cent for road and prisons projects, while others, such as school and hospital schemes, illustrated more marginal savings of approximately 2 to 4 per cent. However, Maltby (2003) casts doubt over these conclusions by pointing out that of the 378 PPPs completed by central and local government by 2002 only 23 projects ( 6 per cent) had been subject to an independent VFM examination. Indeed, Shaoul et al. (2006) found that eight early roads projects were more costly under PPP than they would have been under conventional procurement.

While there have undoubtedly been successful PPPs, the public record is also 'littered with reports by auditors-general and academic analysts and general press comment drawing attention to weaknesses of the system both potential and actual' (Wettenhall, 2007, p. 394). This raises the question, why, in the face of welldocumented difficulties and limited evidence of success, do governments persist with the adoption of PPP? Institutional and isomorphic theories may help explain the reasons for this.

\section{THE CONCEPTUAL CONTEXT}

The traditional notion of self-contained, bounded organisations with distinct purposes and behaviours, as evidenced by the formal organisation, has been questioned by institutional theorists, particularly with respect to public sector organisations (Meyer and Rowan, 1977; March and Olsen, 1984; Tolbert and Zucker, 1996). Institutional theory views organisations as being immersed in their environments, rather than just interacting with them (Arnaboldi and Lapsley, 2003). 'Technologies are institutionalized and become myths binding on organizations. Technical procedures of production, accounting, personnel selection, or data processing become taken-for-granted means to accomplish organizational ends. Quite apart from their possible efficiency, such institutionalized techniques establish an organization as appropriate, rational, and modern. Their use displays responsibility and avoids claims of negligence' (Meyer and Rowan, 1977, p. 344).

Indeed, institutional theory can help explain why organisations, including governments, are so similar (DiMaggio and Powell, 1983). Scott (1987) and Goodsell (1997) argue that organisational structure is an adaptive vehicle, and institutionalisation refers to evolutionary adaptive processes. They highlight the importance of the symbolic aspects of organisations, and government organisations are good examples of this phenomenon. For example, using PPPs to deliver government policy symbolises a variety of concepts such as achieving better VFM, 
transferring risk, the inherent association of the private sector with efficiency and solving the infrastructural deficit.

But why do governments, and their organisations, adopt similar policies and structures in the face of widespread criticism of such practices? For example, Cohen and Eimicke (2001) concluded that it is not uncommon for government projects to be initiated because they are in vogue and that there is frequently a lack of a sound business plan and cost-benefit analysis before launching these initiatives. With respect to the introduction of RAB, Connolly and Hyndman (2006) concluded that the production of accurate cost information, either in advance or as part of an ex post evaluation, was unlikely to be welcomed by those promoting RAB. Indeed, interviews revealed that while no department had budgeted for the introduction of $\mathrm{RAB}$, or kept records of the actual costs of implementing RAB, they were perceived as being substantial.

Possible answers to this question at the level of the individual government organisation may be related to the process of adapting to the environment and pressures of legitimacy and economic efficiency. Cohen and Eimicke (2001) suggested that the proliferation of e-government initiatives was a defensive reaction to the need to appear to be on the cutting edge and that government organisations obtained funding for projects by convincing senior management that the internet was the only way forward. Funding was more of a function of fashion than an analysis of cost savings or expected benefits, with officials assuming that the use of the internet would increase customer satisfaction (Cohen and Eimicke, 2001). Meyer and Rowan (1977) contend that the social evolution of organisations, and hence their survival, can rest on the observation of formal structures and procedures. Therefore, government organisations may enthusiastically embrace new practices and policies because of pressures of symbolic meanings (social legitimacy) and pressures to conform to commonly adopted action-generating properties (efficiency and productivity gains). Moreover, conformity with the myths (for example, PPPs provide better VFM than traditional procurement) is not enough by itself, the organisation must also maintain the appearance that these myths actually work (Meyer and Rowan, 1977). This is supported by Gold (1999), who suggests that legitimacy is sometimes more important than the rational decision-making processes.

Indeed, Bowerman (2002) contends that governments and their organisations may not only adopt certain policies and practices because of legitimisation needs but also due to resulting isomorphic pressures. DiMaggio and Powell (1983) delineate two kinds of isomorphism - competitive and institutional. The former represents the force of efficiency when there is one best, cheapest or most efficient way for doing things, while the latter includes the rules, symbols and beliefs to which individual organisations must conform to gain social legitimacy. They suggest that competitive isomorphism, whilst explaining the process of bureaucratisation, is inadequate as an explanation of current isomorphic trends. However, as institutional isomorphism confers legitimisation, it is leading to similarity in institutional forms (Meyer and Rowan, 1977; DiMaggio and Powell, 1983; Meyer, 1994). This may help explain policy transfer of the kind discussed in this paper, where institutional forms and processes are adopted by different 
governments in different countries. DiMaggio and Powell (1983) suggest a number of mechanisms that promote institutional isomorphism: coercion, mimicry and normative pressures.

Hassan (2005) refers to coercive institutional isomorphism as the formal and informal pressures, often through legislation or the need for resources, exerted on organisations by other organisations. Government organisations may be 'coerced' to adopt a particular policy as the result of government mandates and/or informal pressures from other government and private organisations already employing such policies. Although the use of PPPs was not necessarily mandatory in the UK, there is strong intimation that governments expected them to be the preferred option. When the adoption of mandated functions are enforced or encouraged by monetary incentive, both institutional and resource dependency perspectives may be applicable, since such a development connects isomorphic tendencies to organisations' reliance on resources from their environments (Pfeffer and Salancik, 1978; Tolbert and Zucker, 1996).

Organisations often wish to adopt what is considered 'normal behaviour', especially when there is uncertainty about the correct way to behave, which can result in organisations mirroring other organisations that are deemed to be successful (Hassan, 2005). Government organisations (prompted by central government policies) may mimic the practices of the private sector, which they perceive to be more legitimate and successful, and even model themselves on similar organisations, particularly in response to uncertainty. By imitating these organisations, they enhance their legitimacy by demonstrating at least an attempt to improve service provision. Mimetic isomorphism may also be prevalent in network settings as network members turn to other members for information and new ideas, which again can be tied to resource-dependency arguments. Such networks are prevalent in the public sector and are often formed in response to new policy initiatives such as PPPs.

Normative isomorphic forces describe the effect of professional standards and the influence of professional communities on organisational characteristics. Following the development of new rules or professional norms, government organisations may adopt particular policies. This can be interpreted as a collective effort to define the conditions and methods of work, control the area of action and establish a base of legitimate permission for occupational autonomy. There is strong evidence of normative isomorphism in the adoption of PPPs with (elements of) the accounting profession interpreting the accounting rules in a manner which made the use of PPPs attractive.

As a consequence of institutional pressures (coercion, mimicry and normative), institutional rules are created and organisations adopt these rules to obtain legitimacy (Hassan, 2005). Although DiMaggio and Powell (1983) distinguish between these three strands of isomorphism, they acknowledge that they may become entwined in real life. Moreover, they acknowledge that while early adopters of a new policy may be driven by a desire to improve performance, as the policy spreads a threshold is reached beyond which its adoption proceeds with increasing speed because it provides legitimacy above improved performance. While governments continue to promote the use of PPPs, their popularity 
(and the subsequent transfer of legitimacy) has started to wane. However, this does not imply that organisations that utilise PPPs do so cynically, since, as illustrated previously, there are strong arguments in favour of their use. Khadaroo (2005) adopted an institutional theory perspective when investigating the standard setting process for PPPs in the UK, concluding that HMT seemed to use its coercive power to urge public sector bodies to voice their opposition to the Accounting Standards Board's proposed accounting treatment for PPP-related assets. This paper investigates the application of these theories in the context of the use of PPPs in the Irish education sector.

\section{PPPs IN EDUCATION}

Patrinos and Sosale assert that 'the importance of PPP has been steadily rising both in developed and developing countries' $(2007$, p. 3). Although contracting for education services is uncommon, the PPP model has been adopted in a number of jurisdictions for the purpose of constructing and managing school facilities. The UK announced its first contract in 1996, and since then the model has been used in countries such as Australia, Canada, Germany and the Republic of Ireland (RoI). Evidence with regard to the impact of adopting PPPs in the education sector is relatively scarce (Patrinos and Sosale, 2007) and, where available, tends to cover procurement or early implementation and does not provide definitive conclusions about achieving VFM. In their study of school PPPs in the UK, Ball et al. (2000, 2001) concluded that the VFM case was uncertain, as key drivers such as better innovation and risk transfer were not guaranteed. They 'identified a movement away from the output specification approach to a more input-oriented approach ... than would have been expected given the literature surrounding the PFI' (Ball et al., 2000, p. 166). The authors assert that the private sector is reluctant to take on risk and they demonstrate how it negotiated to reduce exposure to risks such as residual value risk, which can have strong incentive effects and improve prospects for VFM. These findings are largely consistent with those published by the UK Audit Commission, which concluded that 'the early PFI schools in our sample were not better designed, and were not achieving efficiency savings in terms of the cost and quality of FM [facilities management] services' (2003, p. 41). Furthermore, whilst awarding a contract on the basis of the most economically advantageous tender may seem obvious, contracts have been awarded on the basis of the overall price, which does not always result in the most cost-effective solution (for example, see Edwards and Shaoul (2003) for a discussion of the Pimlico schools project).

A post-implementation review of the first school PPP procured by the government of New South Wales in Australia found that 'many participants [in the survey] felt that innovation was lacking in the facility design area' (New South Wales Treasury, 2005, p. 1). This was attributed to a number of factors, such as the affordability cap ${ }^{4}$ probity requirements, which limited the extent of interaction between the public sector and bidders, and the desire to protect minimum facilities standards. On the question of risk transfer, the review found that the contract 
included a 25 per cent cap on monthly performance deductions. This feature, which was based on the approach adopted in similar contracts for PPP schools in the UK, has the impact of blunting the incentives for better private sector performance and was highlighted as a matter for concern by the review. Taken together, the findings in relation to innovation and risk transfer - two key drivers of VFM - raise questions about the potential for achieving VFM in education.

Although a similar post-implementation review conducted by Partnerships UK (2005) found a considerable level of satisfaction on the part of stakeholders, it also reported a significant increase in resource requirements on the part of PPP schools; significant levels of concern about the usability of the payment mechanism; problems with the output specifications, especially where the quality or performance level or standard is not objectively measurable; and concern that provisions for variations and small works requirements were inadequately specified in the contract, leading to concerns of overcharging by contractors. Indeed, McFadyean and Rowland (2002) believed that the governors of PPP schools were having their powers taken away, even though their responsibilities remained. Further ex post analyses of PPP in education have been carried out by Ismail and Pendlebury (2006) and Kakabadse, Kakabadse and Summers (2007). Both studies investigated how the initiative was impacting on users, with the former examining schools and the latter Local Education Authorities (LEAs). Ismail and Pendlebury (2006) concluded that some schools faced problems with regard to affordability, the management of the contract and VFM, but that there were higher satisfaction levels regarding the quality of the buildings. Kakabadse et al.'s (2007) findings support the notion of coercion, with 40 per cent of the LEAs analysed believing that funding was only available through PPP. They also found that while there were concerns about the initiative's expense and complexity, there were high levels of satisfaction with the underlying facilities.

Overall, while the evidence on PPP performance in the education sector is less than positive and there are grounds for scepticism about its ability to deliver VFM, the model continues to be heavily advocated. Governments, including those of the RoI and UK, are promoting PPPs as the most efficient way of providing public sector services, with government organisations adopting the model to gain social legitimacy. Both competitive and institutional isomorphism can help to explain this paradox, with the adoption of PPPs in Northern Ireland (NI) and the RoI illustrating why.

\section{The NI Pathfinder Projects}

Four secondary schools and two further and higher education colleges, which were high priorities on the Department of Education for Northern Ireland's (DENI's) planning list and of adequate size (in capital terms) to be attractive to private sector investors, were selected as PPP Pathfinder projects (see Table 1). Each of the contracts was to DBFO the schools/colleges for 25 years.

An evaluation of whether these PPPs offered VFM over conventional procurement concluded that with tighter control, the Pathfinder projects offered cost 
TABLE I: THE NI PATHFINDER PROJECTS

\begin{tabular}{ll}
\hline Project & Capital Development Costs \\
\hline Wellington College, Belfast & $£ 19$ million \\
Balmoral High School, Belfast & \\
$\quad$ (single contract) & \\
St. Genevieve's Secondary School, Belfast & $£ 14$ million \\
Drumglass High School, Dungannon & $£ 7$ million \\
Belfast Institute of Further and Higher Education & $£ 20$ million \\
North West Institute of Further and Higher Education & $£ 7$ million \\
\hline
\end{tabular}

Source: NIAO, 2004.

benefits over traditional procurement (Northern Ireland Audit Office (NIAO), 2004). In terms of timescale, while the initial procurement period took longer, construction time was reduced compared to conventional projects, and it was suggested that this reflected the inbuilt incentives of PPP payment mechanisms, whereby the service provider will only receive payments when the facilities become effective. However, there was evidence of only limited innovation in terms of design and service delivery. Assessing the VFM of the five Pathfinder contracts by comparing the preferred bid against the PSC indicates the savings were small: only two contracts were below the PSC, one was almost similar, while the other two were both above it. Overall, the total value of the agreed contract prices was 2.6 per cent ( $£ 2.9$ million) below their combined PSCs (NIAO, 2004). Furthermore, there has been a major problem with Balmoral High School, with demand forecasts being considerably higher than actual enrolment (Doyle, 2006). However, closing the school was arguably not a viable option (although this has recently occurred) as the education authority would still have to pay the contractor over the 25-year life of the project, and the financial penalties would be severe should it wish to terminate the contract (NIAO, 2004).

If Ghobadian, Gallear, Viney and O'Regan (2007) are correct in their assertion that lessons from previous research on compulsory competitive tendering have not been fully absorbed and similar mistakes are being made in the case of PPPs, it is unsurprising that the NI Pathfinder projects failed to deliver as intended. Indeed, it is reasonable to ask why such a flawed model was even adopted in NI. However, with an education infrastructure badly in need of upgrade, and clear indications from the UK government that PPP was the only game in town, coercive pressures meant there were few alternatives. Horgan believes that due to the need for significant expenditure on NI infrastructure, the NI Executive accepted HMT's 'edict that all the capital projects required to do this could not be undertaken with public money' (Horgan, 2006, p. 662) and that PPP was the only option, supporting the negative perception that PPP was 'the only show in town' (for example, Mayston, 1999; Rutherford, 2003). Indeed, as Health Secretary, Alan Milburn stated that with regard to new hospitals it was 'PFI or bust' (Monbiot, 2002). The case of Balmoral is perhaps an example of the cosmetic or mythical adoption of a private sector practice that can come about under coercive 
pressures. Hassan (2005) states that the cosmetic or mythical adoption of a private sector practice can occur under coercive pressures with organisations implementing policies simply to appease their constituents rather than on a rational decision-making basis. Balmoral High School is perhaps an example of this as the education authority felt obliged to open a school as PPP funding was available, despite the likelihood that there would be insufficient student numbers among the local community.

\section{The RoI Pilot Projects}

PPPs were first introduced in the RoI in 1999. Table 2 indicates that three projects in the education sector have completed the procurement process, with two in operation and one under construction. A further 27 schools or colleges have been earmarked for procurement under PPP (see Table 2).

The five post-primary schools and the Cork School of Music projects illuminate the problems encountered when a new and relatively complex procurement model like PPP is adopted. With respect to the former project, the Irish Comptroller and Auditor General (C\&AG) (2004) reported that the initial VFM exercise estimated PPP cost savings of 6 per cent compared to traditional procurement. However, the C\&AG highlighted a number of significant errors in the original VFM exercise concerning the timing and discounting of payments and the calculation of the residual value of the school buildings at the end of the 25-year contract, estimating that the final PPP deal was 8 to 13 per cent more expensive than under traditional procurement. The report also highlighted significant deficiencies in the procurement process, including a failure to establish an affordability cap for the project and calculate a public sector benchmark (comparator) until after the selection of the preferred bidder. The C\&AG (2004) concluded that although

TABLE 2: THE Rol PILOT PROJECTS

\begin{tabular}{|c|c|c|c|}
\hline Project & Type and Duration & $\begin{array}{c}\text { Contract } \\
\text { Award Date }\end{array}$ & Current Status \\
\hline $\begin{array}{l}5 \text { post-primary schools } \\
\text { bundle }\end{array}$ & DBFO - 25 years & November 200I & $\begin{array}{l}\text { Operational since } \\
\text { January } 2003\end{array}$ \\
\hline $\begin{array}{l}\text { National Maritime } \\
\text { College of Ireland }\end{array}$ & DBFO - 25 years & February 2003 & $\begin{array}{l}\text { Operational since } \\
\text { October } 2004\end{array}$ \\
\hline Cork School of Music & DBFO - 25 years & September 2005 & $\begin{array}{l}\text { Operational since } \\
\text { September } 2007\end{array}$ \\
\hline $\begin{array}{l}4 \text { post-primary schools } \\
\text { bundle }\end{array}$ & DBFO - 25 years & Not applicable & Tender evaluation \\
\hline $\begin{array}{l}5 \text { post-primary schools and } \\
\text { I primary school bundle }\end{array}$ & DBFO - 25 years & Not applicable & Under procurement \\
\hline I 7 third level projects & $\begin{array}{l}\text { DBFO - duration } \\
\text { not available }\end{array}$ & Not applicable & Pre-procurement \\
\hline
\end{tabular}


risks were 'appropriately retained' by the public sector, the extent of risk transfer to the private sector was 'limited' (valued at 6.9 per cent of the overall estimated cost of procuring the schools by conventional means). In relation to the issue of innovation, Hurst and Reeves (2004) questioned the scope for innovation in this project due to the prescriptive nature of specifications provided by the Department of Education and Science (DoES). Moreover, the authors noted that the DoES permitted the contractor to exceed its own space norms when constructing the new schools, thereby undermining scope for determining innovations.

The Cork School of Music project was delayed for over four years after the selection of a preferred bidder due to concerns about affordability as well as issues in relation to the accounting treatment of the PPP. The latter issue arose following confirmation from Eurostat (2004) that the construction costs would be counted in the General Government Balance figures and treated as gross fixed capital formation of general government spread across the period of construction (approximately two years). The only other currently operational scheme, the National Maritime College of Ireland, was comparatively straightforward in terms of contract negotiations and affordability. However, it relies heavily on third-party revenue when the facilities are not in use.

Despite these problems, there remains a commitment to the use of PPPs in the RoI education sector. Indeed, in October 2005 the DoES announced the decision to procure a further 10 schools, together with 17 projects in the tertiary sector, under PPP. Whilst coercion offers the most convincing explanation for the adoption of PPP schools in NI, mimicry better explains their establishment in the RoI. Ghobadian et al. suggest mimetic pressure 'allows the manager a degree of selfdetermination in realising the course to pursue, although the theory suggests that the eventual outcome will still be characterised by relative homogeneity' (2007, p. 376). As an independent state, the RoI was free to adopt whatever public sector procurement model it considered most suitable; indeed at this time the RoI would not have been under the same financial pressures as the UK. However, despite having the opportunity to learn from the more negative aspects of PPPs in the UK and elsewhere, significant problems were still encountered. Moreover, the DoES has persisted with the PPP model and sought legitimacy through its adoption.

\section{DISCUSSION AND CONCLUSION}

The modernisation agenda in the RoI and UK extends across the entire public sector. This paper focuses on the use of PPPs as a policy tool in this process. It draws on institutional theory to explore the manner in which PPPs have been introduced, and in particular ideas of institutional isomorphism as a possible explanation for the manner in which PPPs have been promoted. Isomorphism can involve mimicry, of both private sector practices and of other similar organisations and countries/governments that are perceived to be successful and modern, as the means by which public sector institutions present themselves as progressive. Consequently, government organisations may adopt policies (such as PPP) because they are advocated by central government, particularly where there are 
coercive forces at play, as is the case with PPPs in the UK, which are often seen as 'the only show in town'. In this way, central government and the adopting organisations portray themselves, initially at least, as modern and progressive, with the legitimisation that this confers. However, governments, and their organisations, should only embark on new initiatives if they are convinced of a practical benefit. If conferment of legitimacy is the desired outcome, they should wait until the 'bandwagon' is rolling towards an acceptable destination before joining it.

Institutional pressures have played a role in the use of PPPs by government organisations, with some PPPs being initiated partly because of legitimacy concerns, such as keeping up with other organisations or being seen to be proactive, as well as more rational motives such as improving VFM. However, the conferment of legitimacy can be unstable and subject to change as an initiative progresses (Bowerman, 2002). Additionally, legitimacy is fragile and can be marred by intense scrutiny. While it can be important to harness these coercive, isomorphic forces to further policy aims, this can lead to unintended consequences. Consistent with Kingdon's (1990) argument that public policy is often not developed in a systematic, rational manner (agenda setting, formulation, implementation and evaluation), the PPP agenda-setting stage appears to be following the garbage can model of decision making (Cohen and March, 1972). In other words, specific solutions are not created to solve specific problems as a rational planning model would assume, but rather organisations sift through the 'garbage' to find a possible solution, which in the case of PPP also found a receptive political environment.

The motivation for the use of PPPs is similar in both the RoI and UK: a desire to improve the public sector infrastructure, whilst staying within public spending limits. However, the background differs slightly. Although both jurisdictions adopted PPP following years of under-spending on infrastructure due to other political priorities, an added dimension in the RoI was the desire to ensure the country's infrastructure kept pace with the rapid economic growth it was experiencing. Seven years after the initial launch of PPPs in the UK in 1992 (and three years after the first PPP school contract in England and Scotland), it was announced that PPPs were to be used in NI and the RoI to build new schools and colleges. However, it would appear that little was learnt from the British experience. Both NI and the RoI installed similar institutions to their British counterparts and, although various reports had criticised the poor design, lack of innovation, limited risk transfer and unrealised VFM in these earlier projects, the $\mathrm{NI}$ and RoI education projects experienced similar problems. In NI, only two out of the five Pathfinder contracts were marginally cheaper than the PSC (a framework that is often deemed to be biased in favour of a private sector bid as it overestimates the cost of the hypothetical public sector submission), one was the same and the remaining two were more expensive. In the RoI, the first bundle of PPP schools was 8 to 13 per cent more expensive than under traditional procurement (C\&AG, 2004).

Such experiences are not limited to the education sector, with, for example, projects in the UK health sector being widely criticised for a lack of VFM (Gaffney and Pollock, 1999; Mayston, 1999; Froud and Shaoul, 2001; Broadbent et al., 2003). Despite this, the use of PPPs shows no sign of abating with deals amounting to 
$£ 11$ billion expected to be in place by 2010 in the UK (HMT, 2006). The RoI government has also maintained faith in the initiative despite, in addition to the problems outlined earlier, constraints on spreading the cost of construction over the period of the contract due to a change in the Eurostat (2004) rules. Indeed, it has earmarked 27 PPPs across all three education sectors and preliminary work has commenced in these areas.

The use of PPPs undoubtedly spreads the cost of building and operating public service infrastructure, and it is arguably only fair that future generations of taxpayers pay for assets that they will benefit from. However, as with any 'buy now, pay later' finance deal, the eventual cost is much higher than if expenditure had been made up front. PPPs are appealing to governments as they pass on the cost of rebuilding or refurbishing the infrastructure to future administrations, plus they can be seen to be active in the eyes of voters when it comes to improving public services. While the PPP process has improved, it is still debatable whether it really achieves VFM, and perhaps this issue cannot be fully addressed until some of these long-term contracts come to an end, which is still many years away.

There is evidence that, in the long term, the cost of PPP capital will be higher than the cost of a loan raised by the issue of a public sector bond or low-cost public sector government loan. These higher costs will have to be met from the public purse. While devolving money to schools has allowed them a degree of autonomy and the flexibility to innovate, this autonomy and flexibility could be undermined by PPPs. The payments for PPPs have a legal 'first call' on school revenue in NI and must be paid before any other budget decisions (including the retention or recruitment of teachers) is considered. Consequently, this may limit the ability of school governors to protect the teaching of the curriculum if future funding is reduced.

DiMaggio and Powell's (1983) isomorphic theories help rationalise the introduction of PPPs in the RoI and UK: competitive (whereby PPPs were portrayed to represent the best, cheapest and most efficient way of providing public sector services) and institutional (whereby government organisations had to follow the PPP route to gain social legitimacy). Moreover, in the context of institutional isomorphism, 'coercion' can explain the manner in which PPPs were introduced in the UK, 'mimicry' is more applicable to the RoI and normative pressures provide a reason why elements of the accounting profession interpreted the accounting rules in a manner that made the use of PPPs attractive.

The use of PPPs in education coincided with the devolution of powers to the Northern Ireland Executive. However, a combination of a neglected schools' estate, severe fiscal constraints and an expectant electorate gave the newly formed Executive little choice but to bow to pressure from Westminster. This coercive pressure undermines the ability of managers (principals) and employees (teachers) to adopt new patterns of behaviour, particularly when they have been schooled in a different institutional environment (Ghobadian et al., 2007). As with the RoI (Hurst and Reeves, 2004), whilst some NI principals have coped with their new role as contract negotiator, others have found it more difficult. Furthermore, PPP imposes a more commercial outlook on schools with respect to raising third-party revenue, which is in contrast to the more benevolent community 
perspective that allowed facilities to be used free of charge. In a situation of coercive isomorphism, managers are forced to respond in a certain way by the rules imposed on them (Ghobadian et al., 2007), and they can then 'become compliant through a process of socialisation and identity formation' (Johnson, Smith and Codling, 2000, p. 573). This appears to be the case in NI, where education authorities and principals are willing to implement PPP as it is perceived to be the only means of renewing the schools' estate, despite all the problems with Balmoral High School.

Like NI, the RoI schools' estate had suffered from years of underinvestment. When searching for solutions to rectify this, it is perhaps unsurprising that it was influenced by how its closest neighbour had tackled similar issues. This mimetic isomorphism gave the RoI government a degree of 'self-determination' (Ghobadian et al., 2007). Whilst some aspects of the UK PPP model were copied, the RoI adopted a more social partnership approach (Horgan, 2006), resulting in all parties, including the trade unions, being more supportive of the initiative than in the UK.

If coercive isomorphism is supplanted by mimetic and normative isomorphism, compliance is replaced with the potential for interpretation, innovation and error to influence, challenge and change prior experiences and behaviour (Johnson et al., 2000). The key difference is the location of the impetus: coercion compels certain behaviour, while mimetic and normative isomorphisms allow a degree of self-determination (albeit that the outcome may be characterised by relative homogeneity). This may help explain why, despite a lack of coercive pressure and the opportunity to learn from the UK experience, similar mistakes were made in the RoI education sector with the adoption of PPP.

\section{NOTES}

1 Different political and legislative systems operate in England, Northern Ireland (NI), the Republic of Ireland (RoI), Scotland and Wales. Unless stated otherwise, 'United Kingdom' is used to define England, NI, Scotland and Wales; 'Britain' is used to define England, Scotland and Wales; while 'Ireland' refers to NI and the RoI.

2 It is interesting to note that New Labour repackaged the PFI as part of the wider PPP programme, with some viewing the term PPP as being friendlier sounding and less politically charged (Economist Intelligence Unit, 2002). As noted above, while strictly the PFI is a form of PPP, these terms are now often used interchangeably. Consequently, the term PPP will be used throughout the remainder of this paper.

3 Design, Build, Finance and Operate (DBFO) contracts - these are contractual relationships between the public sector and private sector contractors for the design, construction, operation and financing of public facilities or infrastructure. The private sector contractor is responsible for designing, building, operating and financing the facility and recovers its cost solely out of payments from the public sector. At the end of the contract term, which is often for 25-30 years, ownership of the facility usually transfers to the public sector.

4 The affordability cap provides a reliable assessment of the maximum amount the state is willing to spend. 


\section{REFERENCES}

Arnaboldi, M. and Lapsley, I. (2003). Activity Based Costing, Modernity and the Transformation of Local Government, Public Management Review, Vol. 5, No. 3, pp. 345-375.

Arthur Andersen (2000). Value for Money Drivers in the Private Finance Initiative, report by Arthur Andersen and Enterprise LSE, commissioned by the Treasury Taskforce.

Audit Commission (2003). PFI in Schools: The Quality and Cost of Buildings and Services Provided by Early Private Finance Initiative Schemes, London: Audit Commission.

Ball, R., Heafey, M. and King, D. (2000). Managing and Concluding the PFI Process for a New High School: Room for Improvement?, Public Management, Vol. 2, No. 2, pp. 159-180.

Ball, R., Heafey, M. and King, D. (2001). Private Finance Initiative - A Good Deal for the Public Purse or a Drain on Future Generations?, Policy and Politics, Vol. 29, No. 1, pp. 95-108.

Ball, R., Heafey, M. and King, D. (2003a). Some Lessons from Using PFI for School Building Contracts, Local Government Studies, Vol. 29, No. 2, pp. 89-106.

Ball, R., Heafey, M. and King, D. (2003b). Risk Transfer and Value for Money in PFI Projects, Public Management Review, Vol. 5, No. 2, pp. 279-290.

Benington, J. (2000). The Modernization and Improvement of Government and Public Services, Public Money and Management, Vol. 20, No. 2, pp. 3-8.

Bowerman, M. (2002). Isomorphism Without Legitimacy? The Case of the Business Excellence Model in Local Government, Public Money and Management, Vol. 22, No. 2, pp. 47-52.

British Medical Association (BMA) (1997). Can the NHS Afford the Private Finance Initiative?, London: BMA.

Broadbent, J., Gill, J. and Laughlin, R. (2003). Evaluating the PFI in the NHS in the UK, Accounting, Auditing \& Accountability Journal, Vol. 16, No. 3, pp. 422-445.

Cohen, S. and Eimicke, W. (2001). The Use of Internet in Government Service Delivery, in M. Abramson and G. Means (eds), E-Government 2001, Oxford: Rowman and Littlefield Publishers.

Cohen, M.D. and March, J.G. (1972). A Garbage Can Model of Organisational Choice, Administrative Science Quarterly, Vol. 17, No. 1, pp. 1-25.

Commission on Public Private Partnerships (2001). Building Better Partnerships, London: Institute of Public Policy Research.

Comptroller and Auditor General (2004). The Grouped Schools Pilot Partnership Project, Dublin: The Stationery Office.

Connolly, C. and Hyndman, N. (2006). The Actual Implementation of Accruals Accounting: Caveats from a Case Within the UK Public Sector, Accounting, Auditing $\mathcal{E}$ Accountability Journal, Vol. 19, No. 2, pp. 272-290.

DiMaggio, P. and Powell, W. (1983). The Iron Cage Revisited: Institutional Isomorphism and Collective Rationality in Organisational Fields, American Sociological Review, Vol. 48, No. 2, pp. 147-160.

Doyle, S. (2006). PFI School Has Just 9 New Pupils for September, SecEd, 20 April 2006, <http://www.sec-ed.co.uk/cgi-bin/go.pl/article/article.html?uid=33296; type_uid=1> [Accessed 23 January 2008].

Economist Intelligence Unit (2002). Public v Private, London: The Economist Newspaper Group.

Edwards, P. and Shaoul, J. (2003). Controlling the PFI Process in Schools: A Case Study of the Pimlico Project, Policy and Politics, Vol. 31, No. 3, pp. 371-385. 
Edwards, P., Shaoul, J., Stafford, A. and Arblaster, L. (2004). Evaluating the Operation of PFI in Roads and Hospitals, Association of Chartered Certified Accountants (ACCA) Research Report No. 84, London: ACCA.

Eurostat (2004). New Decision of Eurostat on Deficit and Debt: Treatment of Public-Private Partnerships, Eurostat, 11 February 2004, <http://www.pppcentrum.cz/res/data/ 001/000230.pdf> [Accessed 21 November 2007].

Froud, J. (2003). The Private Finance Initiative: Risk, Uncertainty and the State, Accounting, Organizations and Society, Vol. 28, No. 6, pp. 567-589.

Froud, J. and Shaoul, J. (2001). Appraising and Evaluating PFI for NHS Hospitals, Financial Accountability \& Management, Vol. 17, No. 3, pp. 247-270.

Gaffney, D. and Pollock, A.M. (1999). Pump-Priming the PFI: Why Are Privately Financed Hospital Schemes Being Subsidized?, Public Money and Management, Vol. 19, No. 1, pp. 5-62.

Gaffney, D., Pollock, A.M., Price, D. and Shaoul, J. (1999). The Private Finance Initiative: PFI in the NHS - Is There an Economic Case?, British Medical Journal, Issue 319, 10 July, pp. 116-119.

Ghobadian, A., Gallear, D. Viney, H. and O'Regan, N. (2007). Public Sector Performance Improvement Through Private Sector Management Practices: A Satisfactory Solution?, International Journal of Business Performance Management, Vol. 9, No. 4, pp. 363-379.

Giddens, A. (1998). The Third Way: The Renewal of Social Democracy, Cambridge: Polity Press.

Glaister, S. and Travers, T. (2007). Unchecked and Unwieldy: The Collapse of Metronet Shows the Fatal Flaws of PPP, and the Folly of Relying on Consultants, Guardian Unlimited, 19 July 2007, <http://www.guardian.co.uk/commentisfree/2007/jul/19/ comment.politics1> [Accessed 21 November 2007].

Gold, B.A. (1999). Punctuated Legitimacy: A Theory of Educational Change, Teachers College Record, Vol. 10, No. 2, pp. 192-219, <http://www.tcrecord.org/content.asp? contentid=10438> [Accessed 4 September 2007].

Goodsell, C.T. (1997). Administration as Ritual, International Journal of Public Administration, Vol. 20, Nos. 4-5, pp. 939-961.

Grimsey, D. and Lewis, M.K. (2002). Accounting for Public Private Partnerships, Accounting Forum, Vol. 26, No. 3, pp. 245-270.

Guthrie, J., Olson, O. and Humphrey, C. (1999). Debating Developments in New Public Financial Management: The Limits of Global Theorising and Some New Ways Forward, Financial Accountability \& Management, Vol. 15, No. 3, pp. 209-228.

Hall, J. (1998). Private Opportunity, Public Benefit?, Fiscal Studies, Vol. 19, No. 2, pp. 121-140.

Hassan, M.K. (2005). Management Accounting and Organisational Change: An Institutional Perspective, Journal of Accounting and Organisational Change, Vol. 1, No. 2, pp. 125-140.

Heald, D. (2003). Value for Money Tests and Accounting Treatment in PFI Schemes, Accounting, Auditing \& Accountability Journal, Vol. 16, No. 3, pp. 342-371.

Heald, D. and Geaughan, N. (1997). Accounting for the Private Finance Initiative, Public Money and Management, Vol. 17, No. 3, pp. 11-16.

Hencke, D. (2003). Court Computer Plan Wastes Millions - And Still Doesn't Work, Guardian Unlimited, 11 November 2003, <http://www.guardian.co.uk/uk_news/ story/0,3604,1082416,00.html> [Accessed 21 November 2007].

Her Majesty's Treasury (HMT) (2000). Public Private Partnerships: The Government's Approach, London: The Stationery Office.

Her Majesty's Treasury (HMT) (2006). PFI: Strengthening Long-Term Partnerships, Norwich: The Stationery Office. 
Hodge, G.A. (2004). The Risky Business of Public-Private Partnerships, Australian Journal of Public Administration, Vol. 63, No. 4, pp. 37-49.

Hood, C. (1991). A Public Management for All Seasons?, Public Administration, Vol. 69, No. 1, pp. 3-19.

Horgan, G. (2006). Devolution, Direct Rule and Neo-Liberal Reconstruction in Northern Ireland, Critical Social Policy, Vol. 26, No. 3, pp. 656-668.

Hurst, C. and Reeves, E. (2004). An Economic Analysis of Ireland's First Public Private Partnership, International Journal of Public Sector Management, Vol. 17, No. 5, pp. 379-388.

Ismail, S. and Pendlebury, M. (2006). The Private Finance Initiative (PFI) in Schools: The Experiences of Users, Financial Accountability \& Management, Vol. 22, No. 4, pp. 381-404.

Johnson, G., Smith, S. and Codling, B. (2000). Microprocesses of Institutional Change in the Context of Privatization, Academy of Management Review, Vol. 25, No. 3, pp. 572-580.

Kakabadse, N.K., Kakabadse, A.P. and Summers, N. (2007). Effectiveness of Private Finance Initiatives (PFI): Study of Private Financing for the Provision of Capital Assets for Schools, Public Administration and Development, Vol. 27, No. 1, pp. 49-61.

Khadaroo, I. (2005). An Institutional Theory Perspective on the UK's Private Finance Initiative (PFI) Accounting Standard Setting Process, Public Management Review, Vol. 7, No. 1, pp. 69-94.

Kingdon, J.W. (1990). Agendas, Alternatives and Public Policies, London: Harper Collins.

Kirk, R.J. and Wall, A.P. (2002). The Private Finance Initiative: Has the Accounting Standards Board Reduced the Scheme's Value for Money?, Public Management Review, Vol. 4, No. 4, pp. 529-547.

Maltby, P. (2003). Comparing Cost, Publicservice.co.uk, <http://www.publicservice.co.uk/ pdf/pfi/summer2003/PJ41\%20Paul\%20Maltby\%20ATL.pdf> [Accessed 23 January 2008].

March, J. and Olsen, J. (1984). The New Institutionalism: Organizational Factors in Political Life, American Political Science Review, Vol. 78, No. 3, pp. 734-749.

Mayston, D. (1999). The Private Finance Initiative in the National Health Service: An Unhealthy Development in New Public Management?, Financial Accountability $\mathcal{E}$ Management, Vol. 15, Nos. 3-4, pp. 249-274.

McCabe, W., McKendrick, J. and Keenan, J. (2001). PFI in Schools - Pass or Fail?, Journal of Finance and Management in Public Services, Vol. 1, No. 1, pp. 63-74.

McFadyean, M. and Rowland, D. (2002). PFI vs Democracy? School Governors and the Haringey Schools PFI Scheme, London: Menard Press.

McKendrick, J. and McCabe, W. (1997). An Observer's Tale: Stonehaven Community Hospital, Public Money and Management, Vol. 17, No. 3, pp. 17-20.

McKendrick, J. and McCabe, W. (1999). PFI - The Holy Grail?, Irish Accounting Review, Vol. 6, No. 2, pp. 31-49.

Meyer, J. (1994). Rationalised Environments, in J. Meyer and W. Scott (eds), Institutional Environments and Organizations: Structural Complexity and Individualism, London: Sage Publications.

Meyer, J.W. and Rowan, B. (1977). Institutionalized Organizations: Formal Structure as Myth and Ceremony, American Journal of Sociology, Vol. 83, No. 2, pp. 340-363.

Monbiot, G. (2002). Private Affluence, Public Rip Off, The Spectator, 10 March.

National Audit Office (NAO) (1997). The PFI Contracts for Bridgend and Fazakerley Prisons, HC 253 Parliamentary Session 1997-1998, London: The Stationery Office.

National Audit Office (NAO) (1999). Examining the Value for Money of Deals Under the Private Finance Initiative, HC 739 Parliamentary Session 1998-1999, London: The Stationery Office. 
National Audit Office (NAO) (2002). PFI Refinancing Update, HC 1288 Parliamentary Session 2001-2002, London: The Stationery Office.

National Audit Office (NAO) (2003). PFI: Construction Performance, HC 371 Parliamentary Session 2002-2003, London: The Stationery Office.

New South Wales Treasury (2005). New Schools Privately Financed Project Post Implementation Review, New South Wales Treasury, December 2005, <http://www. nzcid.org.nz/downloads/NSW\%20New\%20Schools\%20Privately\%20Financed \%20Pr oject \%20Post \%20Implementation\%20Review.pdf > [Accessed 23 January 2008].

Northern Ireland Audit Office (2004). Building for the Future: A Review of the PFI Education Pathfinder Projects, London: The Stationery Office.

Osbourne, S. (2000). Public-Private Partnerships for Public Services: An International Perspective, London: Routledge.

Partnerships UK (2005). Schools PFI - Post Signature Review, London: The Stationery Office.

Patrinos, H.A. and Sosale, S. (2007). Public-Private Partnerships in Education, in H.A. Patrinos and S. Sosale (eds) Mobilizing the Private Sector for Public Education: A View from the Trenches, Washington, DC: World Bank Publications.

Pfeffer, J. and Salancik, G. (1978). The External Control of Organizations: A Resource Dependence Perspective, New York, NY: Harper \& Row.

Pollitt, C. and Bouckaert, G. (2000). Public Management Reform: A Comparative Analysis, Oxford: Oxford University Press.

Pollock, A., Shaoul, J. and Vickers, N. (2002). Private Finance and 'Value for Money' in NHS Hospitals: A Policy in Search of a Rationale?, British Medical Journal, Vol. 324, No. 7347, pp. 1205-1209.

PricewaterhouseCoopers (PWC) (2005). Delivering the PPP Promise - A Review of PPP Issues and Activity, London: PricewaterhouseCoopers.

Reeves, E. (2003). Public-Private Partnerships in Ireland: Policy and Practice, Public Money and Management, Vol. 23, No. 3, pp. 63-170.

Rutherford, J. (2003). PFI: The Only Show in Town, Soundings, Vol. 24, July, pp. 41-54.

Scott, W.R. (1987). The Adolescence of Institutional Theory, Administrative Science Quarterly, Vol. 32, No. 4, pp. 493-511.

Shaoul, J., Stafford, A. and Stapleton, P. (2006). Highway Robbery? A Financial Analysis of Design, Build, Finance and Operate (DFBO) in UK Roads, Transport Reviews, Vol. 26, No. 3, pp. 257-274.

Tolbert, P.S. and Zucker, L.G. (1996). The Institutionalization of Institutional Theory, in S.R. Clegg, C. Hardy and W.R. Nord (eds), Handbook of Organisational Studies, London: Sage Publications.

Wakefield, J. and Valentine, J. (2001). Learning Through Partnership: Private Finance and Management in the Delivery of Services for London, Public Money and Management, Vol. 21, No. 4, pp. 19-25.

Wettenhall, R. (2007). ActewAGL: A Genuine Public-Private Partnership?, International Journal of Public Sector Management, Vol. 20, No. 5, pp. 392-414. 